\title{
IMPACT OF THE LUMBAR STIFFNESS RELATED TO ARTHRODESIS TO FUNCTIONAL DISABILITY
}

\author{
IMPACTO DA RIGIDEZ LOMBAR ASSOCIADA À ARTRODESE NA LIMITAÇÃO DA \\ CAPACIDADE FUNCIONAL
}

\author{
IMPACTO DE LA RIGIDEZ LUMBAR ASOCIADA CON LA ARTRODESIS EN LA LIMITACIÓN \\ DE LA CAPACIDAD FUNCIONAL
}

\author{
Camila Maribondo Medeiros Ramos ${ }^{1}$, Carlos F W E Romerio², Rodrigo Amaral ${ }^{3}$, Carlos Eduardo Algaves Soares de Olivelra ${ }^{1}$, Raphael de Rezende Pratali ${ }^{1}$ \\ 1. Hospital do Servidor Público Estadual de São Paulo, Orthopedics and Traumatology Service, São Paulo, SP, Brazil. \\ 2. Instituto de Coluna e Ortopedia de Recife (InCore), Recife, PE, Brazil. \\ 3. Instituto de Patologia da Coluna, São Paulo, SP, Brazil.
}

\begin{abstract}
Objective: To assess the impact of stiffness associated with lumbar spinal fusion on disability and quality of life. Methods: This is a retrospective study including 40 patients (mean age: $57.7 \pm 16.2$ ) who underwent spinal surgery with fusion including the lumbar segment and a minimum of 24-month postoperative follow-up. The version translated and adapted to Portuguese of the Lumbar Stiffness Disability Index (LSDI) questionnaire was applied to assess the disability associated with stiffness secondary to lumbar spinal fusion. To quantify postoperative clinical lumbar stiffness / mobility, the Modified-Modified Schober Test (MMST) was applied. Results: There was a moderate negative correlation $(r=-0.320)$, but significant $(p=0.04)$, between the MMST value and the LSDI score. The average of LSDI score in patients with extension of spinal fusion to the sacrum was higher than in patients without extension to the sacrum $(p=0.002)$, indicating greater disability in those with extension to the sacrum. Conclusions: In patients undergoing lumbar spinal fusion, the disability related to lumbar stiffness, measured by the LSDI score, was directly related to clinical lumbar stiffness, measured by the modified-modified Schöber test. The inclusion of the sacrum in fusion showed an association with worsening of disability related to lumbar stiffness. Level of evidence III; Retrospective analysis.
\end{abstract}

Keywords: Spine; Arthrodesis; Quality of Life; Range of Motion, Articular.

\section{RESUMO}

Objetivo: Avaliar o impacto da rigidez associada a artrodese lombar sobre a capacidade funcional e qualidade de vida. Métodos: Trata-se de

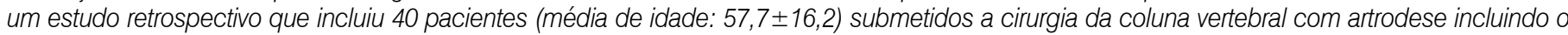
segmento lombar, com mínimo de seguimento pós-operatório de 24 meses. A versão traduzida e adaptada paro o Português do questionário Lumbar Stiffness Disability Index (LSDI) foi aplicada para avaliar as limitações funcionais associadas à rigidez secundária à artrodese lombar. Para quantificar a rigidez/mobilidade clínica lombar pós-operatória, foi aplicado o teste modificado-modificado de Schöber (TMMS). Resultados: Houve correlação negativa moderada $(r=-0,320)$, porém significativa $(p=0,04)$, entre o valor do TMMS e o escore $L S D I$. A média do escore LSDI dos pacientes com extensão da artrodese ao sacro foi maior que nos pacientes sem extensão ao sacro $(p=0,002)$, indicando maior limitação funcional naqueles com extensão ao sacro. Conclusões: Em pacientes submetidos à artrodese da coluna lombar, a capacidade funcional relacionada a rigidez lombar, medida pelo escore LSDI, se mostrou diretamente relacionada com a rigidez lombar clínica, medida pelo teste modificado-modificado de Schöber. A inclusão do sacro na artrodese mostrou associação com piora da capacidade funcional relacionada à rigidez lombar. Nível de evidência III; Análise retrospectiva.

Descritores: Coluna Vertebral; Artrodese; Qualidade de Vida; Amplitude de Movimento Articular.

\section{RESUMEN}

Objetivo: Evaluar el impacto de la rigidez asociada con la artrodesis lumbar en la capacidad funcional y la calidad de vida. Métodos: Este es un estudio retrospectivo que incluyó 40 pacientes (edad media: $57.7 \pm 16.2$ ) que se sometieron a cirugía del artrodesis de la columna, incluido el segmento lumbar, con un mínimo de 24 meses de seguimiento postoperatorio. La versión traducida y adaptada al portugués del cuestionario Lumbar Stiffness Disability Index (LSDI) se aplicó para evaluar las limitaciones funcionales asociadas con la rigidez secundaria a la artrodesis lumbar. Para cuantificar la rigidez / movilidad clínica lumbar postoperatoria, se aplicó la prueba modificada-modificada de Schöber (PMMS). Resultados: Hubo una correlación negativa moderada $(r=-0.320)$, pero significativa $(p=0.04)$, entre el valor del PMMS y el puntaje LSDI. El puntaje promedio de LSDI de pacientes con extensión de artrodesis al sacro fue mayor que en pacientes sin extensión al sacro ( $p=$ 0.002), Io que indica una mayor limitación funcional en aquellos con extensión al sacro. Conclusiones: En pacientes sometidos a artrodesis de columna lumbar, se demostró que la capacidad funcional relacionada con la rigidez lumbar, medida por el puntaje LSDI, estaba directamente relacionada con la rigidez clínica lumbar, medida por prueba modificada-modificada de Schöber. La inclusión del sacro en la artrodesis mostró una asociación con el empeoramiento de la capacidad funcional relacionada con la rigidez lumbar. Nivel de evidencia III; Análisis retrospectivo.

Descriptores: Columna Vertebral; Artrodesis; Calidad de Vida; Rango del Movimiento Articular. 


\section{INTRODUCTION}

Lumbar arthrodesis is a widely-used surgical technique for treatment of various spinal pathologies, including degenerative diseases, traumas, and deformities. ${ }^{1,2}$ The initial objective of the procedure is to obtain fusion between vertebral segments to promote the reestablishment of stability and alignment lost due to pathologies that affect the spine. ${ }^{3,4}$

Although spinal arthrodesis is often effective in relieving pain and providing some degree of functional recovery, the procedure is not without potential issues. Spinal mobility is an integral component of the activities of daily life and the stiffness associated with arthrodesis can lead to limitations on individual functional capacity.,6 Thus, the lumbar stiffness disability index questionnaire was developed in order to better understand the limitations on activities of daily life resulting from stiffness secondary to lumbar spine arthrodesis. ${ }^{7}$

The objective of the present study was to evaluate the impact of stiffness associated with lumbar arthrodesis on functional capacity and the quality of life in order to gain a better understanding of the functional limitations that arthrodesis at different levels of the lumbar spine can cause.

\section{METHODS}

\section{Type of study and population}

This is a retrospective study evaluating 40 patients who underwent spinal arthrodesis surgery, including the lumbar segment. The study was approved by the institutional review board (CAAE: 82012017.6.0000.5463) and all patients signed the informed consent form. Patients who underwent spine surgery with arthrodesis, the extent of which included at least one lumbar segment (from L1-L2 to L5-S1), for the treatment of degenerative diseases, traumas, or deformities of the spine, with minimum postoperative follow-up of 24 months were included. Patients whose arthrodesis extended only as far as T12-L1 were not included, since we consider said segment to be the transition between the thoracic and lumbar spines and without the same biomechanics as the lumbar spine.

Patients who had undergone surgical procedures to treat oncologic conditions were excluded because systemic compromise from the disease can interfere with the functional capacity assessment. Patients with other associated orthopedic diseases such as sacroiliitis, coxarthrosis, gonarthrosis, and pseudarthrosis in bones of the lower limb were also excluded. Another exclusion factor was the occurrence of complications associated with the spine surgery, such as loosening of the implants, pseudarthrosis, or adjacent level disease, which were limiting the postoperative functional assessment.

\section{Data collection}

All the patients who met the inclusion and exclusion criteria were invited to participate in the study. Those who accepted moved on to the data collection phase. Demographic data, including sex, age, age at the time of surgery, and duration of follow-up, were considered, in addition to information about the surgical procedure, especially the extent of the arthrodesis. The version of the LSDI questionnaire translated and adapted for Brazilian Portuguese ${ }^{8}$ was applied to evaluate limitations on the activities of daily life due to stiffness secondary to lumbar spine arthrodesis. The higher the LSDI score, the greater the functional limitation indicated by the patient.

To quantify clinical postoperative lumbar stiffness/mobility, the modified-modified Schöber test (MMST) ${ }^{9}$ was administered to the patients. With the patient in orthostatism, the evaluator locates and demarcates the posterior superior iliac spine, also making a corresponding mark in the midline of the spine (caudal mark). Then, a point is drawn 15 centimeters above this caudal mark. Finally, the patient flexes the trunk with the knees in extension and the new distance between the points is calculated. The MMST value is indicated by the difference obtained between the two measurements. The lower the MMST value, the greater the lumbar stiffness.

\section{Statistical analysis}

The statistical analysis was conducted using SPSS v.20 software (IBM Corp., Armonk, NY, USA). The normality of the distribution of the samples was analyzed using the Shapiro-Wilk test. The linear correlation between the LSDI score and the number of arthrodesed levels, as well as between the LSDI score and the MMST measurement, were analyzed using the Spearman rank correlation test.

The patients were then divided into two groups: Group 1, arthrodesis extending to the sacrum; Group 2, arthrodesis not extending to the sacrum. The Mann-Whitney test was performed to compare the LSDI score values between the two groups.

A value of $p<0.05$ was considered for the level of significance.

\section{RESULTS}

\section{Sample}

Eighteen patients (45\%) were male and 22 (55\%) were female. The age of the patients ranged from 18 to 79 , with a mean of 57.7 years of age (standard deviation [SD]: 16.2). The minimum postoperative follow-up time was 2 years, and the maximum was 19 years (mean 7.5 years, SD: 4.2). The mean body mass index (BMI) of the sample was 28 (SD: 4.6).

Correlation between lumbar stiffness and functional limitation

The mean MMST value was $3.75 \mathrm{~cm}$ (SD: $1.5 \mathrm{~cm}$ ), ranging from 0 to $7 \mathrm{~cm}$. (Table 1) The mean LSDI score was 41.7 (SD: 20.6), ranging from 0 to 75 . (Table 1, Figure 1) There was a moderate negative $(r=-0.320)$ but statistically significant $(p=0.04)$ correlation between the MMST value and the LSDI score. (Figure 2)

\section{Arthrodesis levels and functional limitation}

Regarding the levels of the lumbar spine arthrodesis, only one level was involved in most patients (18, 45\%). (Table 2) Eleven (27.5\%) patients had arthrodesis in two levels, five (12.5\%) in three levels, five $(12.5 \%)$ in four levels, and only one patient (2.5\%) with all five lumbar levels involved in the arthrodesis. There was no correlation between the number of levels involved in the lumbar arthrodesis and the LSDI score $(p=0.160)$.

\section{Influence of the extension of the arthrodesis to the sacrum on functional limitation}

In the sample, 22 (55\%) of the patients had arthrodesis extending to the sacrum. (Table 3 ) The mean LSDI score of the patients with extension of arthrodesis to the sacrum was statistically higher than that of patients with arthrodesis that did not extend to the sacrum $(p=0.002)$, (Table 3 , Figure 3 ) indicating greater functional limitation in those with extension to the sacrum.

Table 1. Total sample modified-modified Schöber test and Lumbar Stiffness Disability Index questionnaire score values.

\begin{tabular}{c|c|c}
\hline & MMST (cm) & LSDI \\
\hline Mean (SD) & $3.75(1.5)$ & $41.7(20.6)$ \\
\hline Median & 4.0 & 42.0 \\
\hline Minimum & 0 & 0 \\
\hline Maximum & 7.0 & 75 \\
\hline
\end{tabular}

MMST: modified-modified Schöber test; LSDI: Lumbar Stiffness Disability Index questionnaire; SD: standard deviation.

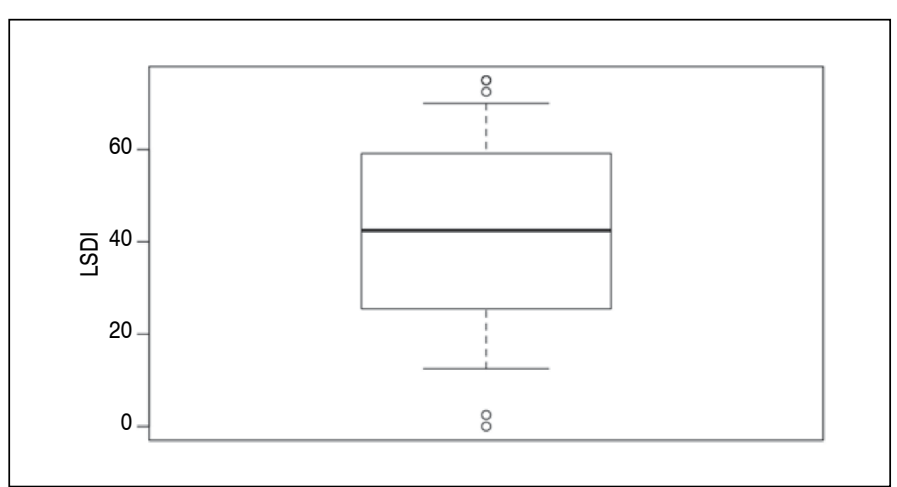

Figure 1. Graph illustrating the distribution of Lumbar Stiffness Disability Index questionnaire scores among the patients of the sample. 


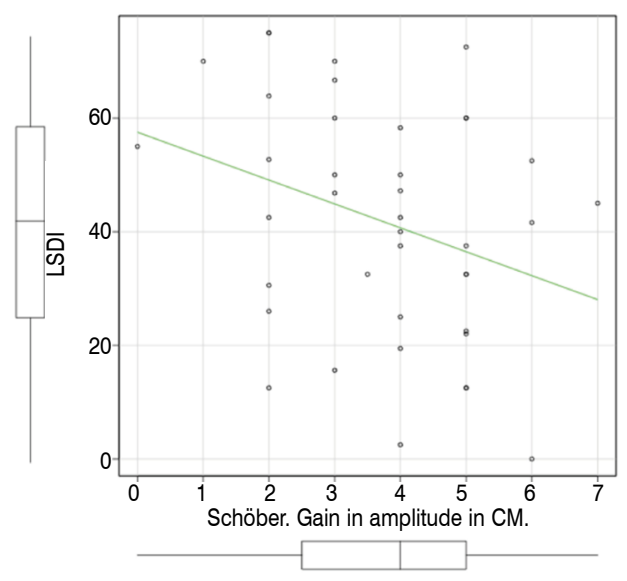

Figure 2. Comparison of the Lumbar Stiffness Disability Index scores between patients with and without extension of the arthrodesis to the sacrum.

Table 2. Lumbar Stiffness Disability Index questionnaire scores by number of arthrodesed lumbar levels.

\begin{tabular}{c|c|c|c}
\hline Number of arthrodesed lumbar levels & $\mathbf{N}(\%)$ & $\begin{array}{c}\text { LSDI } \\
\text { Mean (SD) }\end{array}$ & \multirow{2}{*}{$\mathbf{p}$} \\
\cline { 1 - 3 } & $18(45)$ & $38.9(17.6)$ & \\
\cline { 1 - 3 } 2 & $11(27.5)$ & $44.3(21.5)$ & \multirow{2}{*}{0.160} \\
\cline { 1 - 3 } 3 & $5(12.5)$ & $33.0(31.0)$ & \\
\cline { 1 - 3 } & $5(12.5)$ & $49.2(18.5)$ & \\
\cline { 1 - 3 } & $1(2.5)$ & 67 & \\
\hline
\end{tabular}

N: Number of patients; \%: percent; LSDI: Lumbar Stiffness Disability Index questionnaire; SD: standard deviation.

Table 3. Lumbar Stiffness Disability Index questionnaire scores for patients with and without extension of the arthrodesis to the sacrum.

\begin{tabular}{c|c|c|c}
\hline Extension of arthrodesis to the sacrum & $N(\%)$ & $\begin{array}{c}\text { LSDI } \\
\text { Mean (SD) }\end{array}$ & $p$ \\
\hline YES & $22(55)$ & $51.2(14.9)$ & \multirow{2}{*}{0.002} \\
\hline NO & $18(45)$ & $30.2(20.9)$ & \\
\hline
\end{tabular}

N: Number of patients; \%: percent; LSDI: Lumbar Stiffness Disability Index questionnaire; SD: standard deviation.

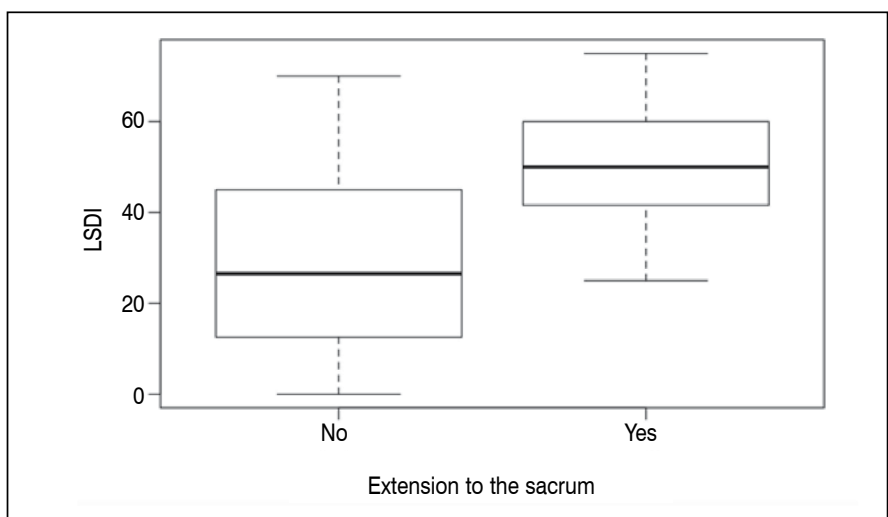

Figure 3. Comparison of the Lumbar Stiffness Disability Index scores between patients with and without extension of the arthrodesis to the sacrum.

\section{DISCUSSION}

The present study demonstrates the impact of stiffness secondary to lumbar spine arthrodesis on the limitation of daily activities in 40 patients with a minimum postoperative follow-up of two years. The treatment of various pathological conditions of the spine through solid intervertebral arthrodesis is widely supported in the literature, 3,4,10,11 despite the knowledge that the loss of segmental mobility associated with arthrodesis can impair, at least to some degree, the functional capacity for different activities. ${ }^{12,13}$ However, a relationship is not yet fully established between the number of levels included in the arthrodesis and either the degree of rigidity or the degree of limitation of functional capacity, especially when the inclusion or not of the sacrum in the arthrodesed levels are compared.

Extension of the arthrodesis to the sacrum has always been viewed as a challenge, both because of considerable levels of fusion failure when compared to arthrodesis without extension to the sacrum and due to a fear of limitation of functional capacity resulting from stiffness in the region of the lumbosacral transition. ${ }^{14-16}$ In the present study, the patients with lumbar arthrodesis without extension to the sacrum had significantly better LSDI scores than the patients with the sacrum included in the arthrodesis, i.e., the addition of the sacrum was associated with greater functional limitation related to stiffness.

In a literature review article, Bridwell et al. observed that the extension of the arthrodesis to the sacrum, in addition to increasing the risk of pseudarthrosis, compromised mobility in the lumbosacral junction, which can change the mechanics of gait due to rigidity of the sacroiliac joints. ${ }^{15}$ On the other hand, Edwards e t al., observed that the extension of arthrodesis to the sacrum in long fusions did not alter the functional outcome as evaluated by the Scoliosis Research Society-24 questionnaire, as compared to patients with arthrodesis extending to L5. ${ }^{17}$

The LSDI questionnaire was developed to assess the limitation of daily activities specifically related to lumbar spinal stiffness after arthrodesis surgery, in order to facilitate understanding of the impact of arthrodesis. ${ }^{7}$ It is an easy to apply and easy to understand tool that has proven to be valid for quantifying functional capacity limitations in these patients. Recently, the LSDI questionnaire was translated into Portuguese and adapted for use in the Brazilian population. ${ }^{8}$

In the present study, it was observed that less lumbar mobility, identified by lower MMST values, was indicative of worse functional capacity in the patients, as represented by higher LSDI scores. This is the first study to show a significant, albeit moderate, correlation between LSDI scores and clinical stiffness identified by the MMST value. Other studies have demonstrated a correlation between the LSDI score and lumbar stiffness evaluated by the range of motion in dynamic lateral radiographs (flexion and extension) of the lumbar spine. ${ }^{7}$ However, this examination cannot be considered the gold standard for evaluating lumbar mobility because of technical limitations, such as being dependent on the way it is executed (operator-dependent), ${ }^{18}$ in addition to exposure to radiation and the costs involved in performing it.

In terms of the number of lumbar levels included in the arthrodesis, the data from this series showed that the functional capacity as measured by the LSDI had no relationship with the number of levels, i.e., worsening of functional capacity was not proportional to the number of arthrodesed levels. This finding is in line with other published studies. Gotfryd et al., observed no difference between the quality of life indicators of patients who underwent single-level arthrodesis and those with arthrodesis in two or more levels. ${ }^{19}$ Hart et al., observed that patients submitted to pan-lumbar arthrodesis, involving all lumbar levels, did not present a worsening of functional capacity related to lumbar stiffness during a minimum of two years of follow-up. ${ }^{20}$

Limitations can be identified in the present study. As it is a retrospective analysis, the preoperative functional capacity data could not be evaluated. Thus, the statement that lumbar arthrodesis causes functional limitations cannot be made. Although the study included 40 patients, considered a robust number compared to other published series, ${ }^{7}$ this number would limit more complex analyses considering specific subgroups.

\section{CONCLUSIONS}

Functional capacity related to lumbar stiffness, measured by the LSDI score in patients who underwent spinal arthrodesis, was shown to be causally related to clinical lumbar stiffness, measured by the modified-modified Schöber test. Inclusion of the sacrum in the arthrodesis was associated with greater impairment of functional capacity related to lumbar stiffness than arthrodesis without extension to the sacrum.

All authors declare no potential conflict of interest related to this article. 
CONTRIBUTION OF THE AUTHORS: Each author made significant individual contributions to this manuscript. Concept and study design: RRP. Data acquisition and IRF approval: RA. Data collection: RA. Analysis and data interpretation: RRP. Development of the article: RRP. Review of the final version for submission: RRP, RA, CEASO, CMMR, CFWER.

\section{REFERENCES}

1. Deyo RA, Gray DT, Kreuter W, Mirza S, Martin BI. United States trends in lumbar fusion surgery for degenerative conditions. Spine (Phila Pa 1976). 2005;30(12): 1441-5. doi: 10.1097/01.brs.0000166503.37969.8a

2. Deyo RA. Back surgery-who needs it? N Engl J Med. 2007;356(22):2239-43. doi: 10.1056/NEJMp078052.

3. Park JJ, Hershman SH, Kim YH. Updates in the use of bone grafts in the lumbar spine. Bull Hosp Jt Dis (2013). 2013;71(1):39-48.

4. Miettinem OS. Quality of life from the epidemiologic perspective. J Chron Dis. 1987:40(6):641-3. doi: 10.1016/0021-9681(87)90028-2.

5. Hart RA, Pro SL, Gundle KR, Marshall LM. Lumbar stiffness as a collateral outcome of spinal arthrodesis: a preliminary clinical study. Spine J. 2013;13(2):150-6. doi: 10.1016/j. spinee.2012.10.014.

6. Hart RA, Marshall LM, Hiratzka SL, Volpi J, Lynn M, Shannon L, et al. Functional limitations due to stiffness as a collateral impact of instrumented arthrodesis of the lumbar spine. Spine (Phila Pa 1976). 2014;39(24):E1468- 74. doi: 10.1097/BRS.0000000000000595.

7. Hart RA, Gundle KR, Pro SL, Marshall LM. Lumbar Stiffness Disability Index: pilot testing of consistency, reliability, and validity. Spine J. 2013;13(2):157-61. doi: 10.1016/j.spinee.2012.12.001.

8. Guarconi Netto A, Marchi L, Pokorny G, Amaral R, Jensen R, Pratali R, et al. Tradução e adaptação do questionário "lumbar stiffness disability index" para o português. Coluna/Columna. 2019;18(2):127-9. doi:10.1590/s1808-185120191802196734.9.

9. Tousignant M, Poulin L, Marchand S, Viau A, Place C. The Modified-Modified Schober Test for range of motion assessment of lumbar flexion in patients with low back pain: a study of criterion validity, intra- and inter-rater reliability and minimum metrically detectable change. Disabil Rehabil. 2005;27(10):553-9. doi: 10.1080/09638280400018411.

10. Andersen T. Videbaek TS, Hansen ES, Bünger C Christensen FB. The positive effect of posterolateral lumbar spinal fusion is preserved at long-term follow-up: a RCT with 11-13 year follow-up. Eur Spine J. 2008;17(2):272-80. doi: 10.1007/s00586-007-0494-8.

11. Glassman SD, Carreon LY, Dimar JR, Campbell MJ, Puno RM, Johnson JR. Clinical outcomes in older patients after posterolateral lumbar fusion. Spine J. 2007:7(5):547-51. doi: 10.1016/j.spinee.2006.11.003
12. Dimar JR 2nd, Glassman SD, Burkus JK, Pryor PW, Hardacker JW, Carreon LY. Two-year fusion and clinical outcomes in 224 patients treated with a single-level instrumented posterolateral fusion with iliac crest bone graft. Spine J. 2009;9(11):880-5. doi: 10.1016/i spinee.2009.03.013

13. Dantas RR, Pratali RR, Motta RL, Barsotti CEG, Santos FPE, Oliveira CEAS. Functional results in patients submitted to surgery for degenerative lumbar disease. Coluna/Columna. 2017;16(4):307-10. doi: 10.1590/s1808-185120171604179116.

14. Bridwell $K H$. Where to stop the fusion distally in adult scoliosis $-L 4$, $L 5$, or the sacrum? In: Pritchard DJ, ed. Instructional Course Lectures, Vol, 45. Rosemont, IL: American Academy of Orthopaedic Surgeons; 1996. p. 101-7

15. Bridwell KH, Edwards CCII, Lenke LG. The pros and cons to saving the L5-S1 motion segment in a long scoliosis fusion construct. Spine (Phila Pa 1976). 2003;28(20):S234-42. doi: 10.1097/01.BRS.0000092462.45111.27.

16. Polly DW Jr, Hamill CL, Bridwell KH. Debate: to fuse or not to fuse to the sacrum, the fate of the L5-S1 disc. Spine (Phila Pa 1976). 2006;31(19S):S179-84. doi: 10.1097/01. brs.0000234761.87368.ee.

17. Edwards CC II, Bridwell KH, Patel A, Rinella AS, Berra A, Lenke LG. Long adult deformity fusions to L5 and the sacrum: a matched cohort analysis. Spine (Phila Pa 1976). 2004;29(18):1996 -2005. doi: 10.1097/01.brs.0000138272.54896.33.

18. Miyakoshi N, Itoi E, Kobayashi M, Kodama H. Impact of postural deformities and spinal mobility on quality of life in postmenopausal osteoporosis. Osteoporos Int. 2003;14(12):100712. doi: 10.1007/s00198-003-1510-4

19. Gotfryd AO, Henriques GG, Poletto PR. Influência da extensão da artrodese lombossacra nos resultados clínicos e funcionais. Coluna/Columna. 2012;11(1):13-6. doi: 10.1590/S180818512012000100001

20. Hart RA, Hiratzka J, Kane MS, Lafage V, Klineberg E, Ames CP, et al. Stiffness after pan-lumbar arthrodesis for adult spinal deformity does not significantly impact patient functional status or satisfaction irrespective of proximal endpoint. Spine (Phila Pa 1976). 2017;42(15):1151-7. doi: 10.1097/BRS.0000000000002006. 